\title{
UZALEŻNIENIE OD SEKSU Z PERSPEKTYWY TEORII PRZYWIAZZANIA
}

\begin{abstract}
Streszczenie
Teoria przywiazania jest jedna z koncepcji psychologicznych wyjaśniających zwiazek wczesnodziecięcych doświadczeń (w relacji z opiekunami) z wieloma problemami $w$ dalszym życiu (zaburzeniami emocjonalnymi, zaburzeniami osobowości, zaburzeniami więzi). Badacze za jej pomoca próbuja też wyjaśnić powstawanie uzależnień, w tym zwłaszcza uzależnienia od seksu. Droga od stylu przywiazania $w$ dzieciństwie do uzależnienia może prowadzić poprzez mechanizm zaburzonej regulacji afektu, mechanizm neurologiczny i poznawczy. W literaturze opisana jest także specyfika rodziny pochodzenia (stylu wychowania, klimatu emocjonalnego) osób uzależnionych od seksu. Dodatkowo na plan pierwszy obok doświadczeń wczesnodziecięcych wytania się etiologia kulturowo-społeczna zachowań seksualnych o cechach uzależnienia. Badacze postuluja by spojrzeć na zachowania seksualne z kategorii hiperseksualizmu, OCSB (out-of-control sexual behaviourzachowanie seksualne poza kontrola) czy uzależnienia od seksu z nowej perspektywy. Przemiany spoleczne, kulturowe $i$ technologiczne sprawity, że o ile do tej pory w grupie ryzyka uzależnień ( $w$ tym uzależnienia od seksu) były głównie osoby $z$ trudnym dzieciństwem, o tyle w obecnej rzeczywistości spotecznej wszyscy sq w grupie ryzyka, a całe otoczenie staje się wielka kultura uzależnień.
\end{abstract}

Słowa kluczowe: przywiazanie, uzależnienie od seksu, regulacja afektu, psychologia rodziny, teoria wstydu, cykl uzależienia, model OAT

* Dr Anna Czyżkowska - psycholog, adiunkt, Wydział Studiów Nad Rodziną, Uniwersytet Kardynała Stefana Wyszyńskiego w Warszawie. 


\section{Wprowadzenie}

Teoria przywiązania jest jedną z bardziej udokumentowanych empirycznie teorii $\mathrm{w}$ psychologii'. Jest też koncepcją wielce użyteczną, ponieważ pozwala zrozumieć, jak nasze wczesnodziecięce doświadczenia (głównie w relacji z rodzicami - relacji przywiązaniowej) rzutują na dorosłe życie ${ }^{2}$. W relacji przywiązaniowej z opiekunem dziecko buduje (na poziomie prewerbalnym) wewnętrzne robocze modele (internal working models) swojej osoby, opiekuna oraz otoczenia (innych ludzi w ogóle) a także relacji, jakie można budować z ludźmi. Ta wiedza idzie z nim na resztę jego życia i jest podstawowym schematem, na bazie którego ocenia siebie, innych oraz swoje relacje z ludźmi. Na podstawie dostępnych mu danych (z własnych doświadczeń) uogólnia tę wiedzę na potencjalne doświadczenia w przyszłości (i zachowuje się potem oraz interpretuje kolejne sytuacje zgodnie z tymi predykcjami). Mówiąc najogólniej doświadczenia wczesnodziecięce mogą być bezpieczne (secure: styl ufny przywiązania) lub pozabezpieczne (insecure: styl ambiwalentno-lękowy, unikający). Trudności w relacji przywiązaniowej z rodzicami mogą być zarzewiem wielu problemów w dorosłym życiu takich jak kłopoty z samoregulacją emocji, problemy z budowaniem więzi z osobami bliskimi (jak przyjaciel, partner/ka czy dziecko) ${ }^{3}$. Współczesne koncepcje genezy uzależnień także podkreślają przywiązanie pozabezpieczne w dzieciństwie jako główne ich źródło ${ }^{4}$.

\section{Teoria przywiązania}

Proces przywiązania pomiędzy rodzicami a dzieckiem zaczyna się w chwili pierwszych kontaktów z nowonarodzonym członkiem rodziny. Jest to mechanizm wrodzony, którego celem jest podtrzymanie własnego życia, przetrwanie ${ }^{5}$. Polega

\footnotetext{
1 M.H. Van Ijzendoorn, C. Schuenge, M.J. Bakermans-Kranenburg, Disorganized attachment in early childhood: meta-analysis of precursors, concomitants, and sequelae, „Developmental Psychopathology” 1999, nr 11(2), s. 225-49.

2 Tamże.

3 Tamże

4 S. Klein, Addiction and Attachment: A Complex Relationship, „Clinical Neuroscience” 2013, Manuscript from Naropa University's Graduate School of Psychology, w: https://www. semanticscholar.org/paper/Running-head-\%3A-ADDICITON-AND-ATTACHMENT-1Addiction-Klein/e81d968c6c6cf6cd6a0d4c023a19d73659f59e98\#related-papers [odczyt: 01.09.2018].

5 J. Bowlby, Przywiazanie, Wydawnictwo Naukowe PWN, Warszawa 2016.
} 
on na tym, że dziecko wysyła sygnały takie jak krzyk, płacz, śmiech, a główny opiekun (najczęściej jest to matka) reaguje na nie w charakterystyczny dla siebie sposób. Opiekunowie reagują na trzy sposoby, co w efekcie buduje trzy główne style przywiązania.

\subsection{Styl bezpieczny (ufny)}

Opiekun reaguje na wszystkie sygnały dziecka, jest dostępny fizycznie i emocjonalnie, szybko i adekwatnie reaguje na sygnały stresu u dziecka, szukając elastycznie sposobu na to, by ten stres zmniejszyć. Opiekun jest sprawnym regulatorem emocji i takiej też regulacji uczy dziecko (które samo nie potrafi regulować swoich emocji, ani ich nawet jeszcze nie rozróżnia i nie rozumie, czuje się zalewane emocjami). W relacji ufnej dominuje klimat pozytywnych emocji, ciepła, radości z relacji z dzieckiem. Opiekun jest osobą zrównoważoną emocjonalnie, wrażliwą i empatyczną. Dostosowuje ilość stymulacji do zapotrzebowania danego dziecka (nie przestymulowuje ani nie zostawia dziecka samego w braku stymulacji).

Dziecko, które doświadczyło relacji ufnej, na prewerbalnym, bazowym poziomie uczy się, że jest osobą wartościową (wartą miłości, tego, by poświęcać mu czas, uwagę), ważną dla opiekuna. Uczy się też, że środowisko w jakim funkcjonuje jest przewidywalne, stabilne, że ludziom (otoczeniu) można zaufać, bo wiadomo czego się można po nich spodziewać (pozytywnych emocji i reakcji). Buduje także poczucie sprawczości (mam wpływ na swoją sytuację - gdy zapłaczę, mama przychodzi i daje ukojenie).

\subsection{Styl ambiwalentny (lękowo-ambiwalentny)}

Opiekun nierównomiernie reaguje na sygnały dziecka, wybiórczo na poniektóre sygnały. Reakcja jest zależna od nastroju opiekuna, na ten sam sygnał opiekun reaguje raz ciepłem, a raz złością (złość to dominująca emocja w stylu ambiwalentnym), przyzwala versus odpycha. Huśtawka emocji i reakcji jest codziennością w relacji ambiwalentnej. Dziecko funkcjonuje w środowisku nieprzewidywalnym. Nie potrafi zaufać opiekunowi, uczy się, że po każdym zachowaniu pozytywnym (ciepłą, empatyczną reakcją na płacz) nastąpi zachowanie negatywne (złość, odepchnięcie).

Opiekun ambiwalentny jest osobą chwiejną emocjonalnie, źle znoszącą stres, nadmiernie skoncentrowaną na sobie i zaabsorbowaną swoimi problemami. Nie ma przez to przestrzeni i pojemności na emocje dziecka, jego płacz, krzyk, stres. Nie potrafi regulować emocji dziecka, ponieważ swoich własnych nie umie regulować. Na stres dziecka reaguje swoim własnych silnym stresem. Bywa osobą 
impulsywną, wybuchową, nieprzewidywalną w swoich reakcjach. Z drugiej strony bardzo potrzebuje bliskości z dzieckiem i buduje ją, gdy chwilowo jest w dobrej kondycji psychicznej.

Dziecko na poziomie bazowym uczy się, że nie zawsze zasługuje na uwagę czy miłość (miłość warunkowa - może jak będę grzeczny, opiekun znów będzie dla mnie dobry, może zrobiłem coś źle, co spowodowało jego wybuch). Uczy się także, że ludzie są nieprzewidywalni, potrafią być dobrzy, czuli i opiekuńczy ale zawsze płaci się potem wysoką cenę za tę chwilową bliskość. Otoczenie jawi mu się jako niebezpieczne, nie wiadomo czego się można spodziewać. Można się starać o miłość ale nigdy się nie będzie dość dobrym i w efekcie nigdy się na nią nie zasługuje. Buduje także niejasne poczucie sprawczości (czasem mam wpływ na swoją sytuację - gdy zapłaczę, mama przychodzi i daje ukojenie; w innej sytuacji, gdy zapłaczę mama nie przychodzi lub przychodzi i krzyczy na mnie, nie wiem od czego zależy jej zachowanie, ciągle szukam odpowiedzi na pytanie, co mógłbym robić lepiej, by uzyskiwać więcej reakcji pozytywnych, a mniej negatywnych).

\subsection{Styl unikający (lękowo-unikający)}

Opiekun unika kontaktu z dzieckiem, postrzega je jako zagrażające, boi się bliskości. Nie reaguje na sygnały dziecka. Próbuje uniknąć bliskości stosując sztywne granice, reguły, zasady w relacji z dzieckiem, od których nie ma ustępstw. Ta sztywność i struktura daje mu ochronę przed nadmiernym wpływem dziecka na jego życie. Unika odczuwania i okazywania emocji. Takie osoby często wkrótce po narodzinach „oddają dzieci na wychowanie” na większość dnia-placówkom, babciom, opiekunkom. Główną strategią w relacji unikającej jest kontrola, a główną emocją lęk. Opiekun unikający jest osobą zahamowaną, odczuwającą silny lęk przed emocjami i przed bliskością, chroni się przed tym za pomocą wzmożonej kontroli w relacjach z ludźmi oraz unikaniem bliskości.

Dziecko na poziomie bazowym uczy się, że nie zasługuje na uwagę i miłość (nie jest tego warte). Uczy się także, że ludziom nie można zaufać ani się do nich zbliżyć (nigdy, bez wyjątków), a otoczenie jest zagrażające. Bliskość z drugim człowiekiem nie jest możliwa. Nie buduje poczucia sprawczości (nie mam wpływu na swoją sytuację - gdy zapłaczę, mama nie przychodzi i nie daje ukojenia, nie reaguje adekwatnie do moich sygnałów).

Czynniki, które wpływają na proces przywiązania (oraz jego jakość - czy zbudowane zostanie styl lękowy czy bezpieczny przywiązania) to: 
- cechy matki i jej reagowanie na potrzeby dziecka (matka jest regulatorem emocji dziecka) ${ }^{6}$,

- reprezentacja dziecka w umyśle matki ${ }^{7}$,

- $\quad$ patologia (dziecka, matki, otoczenia) ${ }^{8}$,

- relacja małżeńska (atmosfera, wychowanie, reprezentacja ojca w umyśle matki) i wsparcie społeczne?.

Relacja rodzic-dziecko przechowywana jest w pre-werbalnym systemie pamięciowym, uaktywnia się w każdej istocie ludzkiej na zasadzie automatyzmów, mimo chęci zmiany najczęściej w sposób niekontrolowany powtarzamy w relacji $\mathrm{z}$ dziećmi własne relacje $\mathrm{z}$ dzieciństwa ${ }^{10}$. Wykształcony $\mathrm{w}$ dzieciństwie wzorzec przywiązania w dalszym życiu wpływa (poprzez mechanizm behawioralny, neurologiczny i poznawczy) na:

- schemat funkcjonowania w relacjach społecznych (w tym z partnerem/ partnerką),

- odczytywanie i wyrażanie oraz tolerowanie własnych emocji (regulacja afektu),

- poczucie własnej wartości, sprawczości,

- rozwój samodzielności, kompetencji społecznych, radzenie sobie ze stresem,

- $\quad$ ryzyko zaburzeń psychicznych i zaburzeń więzi ${ }^{11}$.

Więź oraz specyficzny styl przywiązania trwa przez większość życia. W dorosłym życiu pojawiają się kolejne osoby znaczące (important others), z którymi budujemy więź (partnerzy, małżonkowie, kochankowie) lub z którymi nie potrafimy zbudować bezpiecznego stylu przywiązania ze względu na specyficzne doświadczenia z dzieciństwa. Teoria przywiązania jest jedną z koncepcji wyjaśniających

6 C. Magai, Affect, imagery and attachment. Working models of interpersonal affect and the socialization of emotion, w: Handbook of attachment, red. J. Cassidy, P.R. Shaver, Giulford Press, New York, London 1999.

7 B. Cramer, D.N. Strern, Ocena zmian w krótkoterminowej terapii diady matkadziecko, „Nowiny Psychologiczne” 1990, nr 5-6, s. 92-121.

8 K. Lyons-Ruth, D. Jacobvitz, Attachment disorganization: Unresolved loss, relational violence and lapses in behavioral and attentional strategies, w: Handbook of attachment, red. J. Cassidy, P.R. Shaver, Guilford Press, New York, London 1999.

9 J. Cassidy, P.R. Shaver, Handbook of attachment. Theory, research and clinical applications, The Guilford Press, New York - London 2008.

10 D. Senator, Więź w triadzie matka-ojciec-dziecko jako matryca rozwoju psychicznego dziecka, „Psychologia Rozwojowa - Rodzina jako środowisko rozwoju dzieci i rodziców” 2004, nr 9(2), s. 11-16.

11 D. Senator, Więź... dz. cyt. 
wiele zaburzeń w dalszym życiu (zaburzeń emocjonalnych, zaburzeń osobowości, zaburzeń więzi) ${ }^{12}$. Badacze za jej pomocą próbują też wyjaśnić powstawanie uzależnień, w tym zwłaszcza uzależnienia od seksu' ${ }^{13}$.

\section{Uzależnienia a przywiązanie}

\subsection{Pionierzy - historycznie}

Pierwszym teoretykiem, który w latach 1970-tych opisał związek uzależnień z przywiązaniem był Edward Khantzian ${ }^{14}$. Wraz z Davidem Duncanem stworzył on Hipotezę Samoleczenia (Self-Medication Hypothesis - SMH) ${ }^{15}$. Zgodnie z ich koncepcją podatność na uzależnienia ma u podstaw niezdolność do rozumienia i tolerowania własnych emocji. Uzależnienie według nich nie jest szukaniem przyjemności, a szukaniem ukojenia dla trudnych emocji, erzacem bliskości. W odpowiedzi na zaburzenia samoregulacji jednostka samoleczy się (alkoholem, narkotykami, seksem itp.), by tę regulację uzyskać. Osoby uzależnione funkcjonują bez bliskich relacji interpersonalnych oraz z zaburzonym poczuciem własnego Jaw alienacji od innych i od siebie samego, co z kolei umacnia zależność od substancji czy czynności (gdy nie mogę polegać na sobie, ani na innych) ${ }^{16}$. Idąc tym tropem Höfler i Kooyman ${ }^{17}$ wprost nazwali uzależnienie budowaniem przywiązania do substancji (czynności) zamiast do ludzi.

Osobą, która na szeroką skalę upowszechniła koncepcję powiązań między przywiązaniem a uzależnieniami jest Philip Flores (autor książki „Addiction as

12 M.H. Van Ijzendoorn, C. Schuenge, M.J. Bakermans-Kranenburg, Disorganized... dz. cyt.

13 J. Benfield, Sex addiction: the search for a secure base, „Healthcare Counselling \& Psychotherapy Journal" 2018, s. 14-17; J. Benfield, Secure attachment: an antidote to sex addiction? A thematic analysis of therapists' experiences of utilizing attachment-informed treatment strategies to address sexual compulsivity, „Sexual Addiction and Compulsivity” 2018, nr 25(1), s. 12-27.

14 E.J. Khantzian, The Self-Medication Hypothesis of Substance Use Disorders: A Reconsideration and Recent Applications, „Harvard Review of Psychiatry” 1997, nr 4(5), s. 231-244.

15 Tamże.

16 E.J. Khantzian, Reflections on Treating Addictive Disorders: A Psychodynamic Perspective, „The American Journal on Addictions” 2012, nr 21, s. 274-279.

17 D.Z. Höfler, M. Kooyman, Attachment transition, addiction and therapeutic bonding-An integrative approach, „Journal of Substance Abuse Treatment” 1996, nr 13(6), s. 511-519. 
an attachment disorder") ${ }^{18}$. Opisał on szczegółowo, jak przywiązanie do substancji (czy czynności) jest jednocześnie substytutem przywiązania do ludzi oraz przeszkodą w budowaniu relacji międzyludzkich ${ }^{19}$. Substancja (alkohol, narkotyk czy nawet jedzenie) może dawać odczucie posiadania bezpiecznej bazy, zatem zachowania uzależnieniowe są próbą samoleczenia zaburzeń więzi pochodzących $\mathrm{z}$ dzieciństwa ${ }^{20}$. Uzależnienie staje się konsekwencją i sposobem na niemożność zbudowania więzi z drugim człowiekiem, dodatkowo pełniąc funkcję ochronną chroni jednostkę wysoce podatną na zranienie.

\subsection{Uzależnienie prowadzi do problemów z relacjami czy odwrotnie?}

Kolejne badania potwierdziły, że wzorzec reagowania na figury przywiązaniowe jest bliźniaczo podobny do reagowania na substancje w uzależnieniu (na poziomie behawioralnym, poznawczym i emocjonalnym) ${ }^{21}$.

Do niedawna powszechnie uważano, że to uzależnienie jest przyczyną problemów w relacjach interpersonalnych. Badania podłużne sprawdzające czy uzależnienie jest predyktorem późniejszych zaburzeń w relacjach społecznych dały niejednoznaczne wyniki ${ }^{22}$. To doprowadziło badaczy do myśli, że być może kierunek zależności pomiędzy problemami interpersonalnymi a uzależnieniem jest inny. Sprawdzono zatem odwrotny kierunek zależności - być może zaburzone

18 P.J. Flores, Addiction as an attachment disorder, Jason Aronson, New York 2004.

19 Tamże.

20 A. Schindler, R. Thomasius, P. Sack, B. Gemeinhardt, U. KÜStner, J. Eckert, Attachment and substance use disorders: A review of the literature and a study in drug dependent adolescents, „Attachment \& Human Development” 2005, nr 7(3), s. 207-228.

21 J.P. Burkett, L.J. Young, The behavioral, anatomical and pharmacological parallels between social attachment, love and addiction, „Psychopharmacology” 2012, nr 224(1), s. 1-26; M.L. Cooper, P.R. Shaver, N.L. Collins, Attachment styles, emotion regulation, and adjustment in adolescence, ,Journal of Personality and Social Psychology” 1998, nr 74(5), s. 1380-1397; M. Vungkhanching, K.J. Sher, K.M. Jackson, G.R. Parra, Relation of attachment style to family history of alcoholism and alcohol use disorders in early adulthood, ,Drug and Alcohol Dependence” 2004, nr 75(1), s. 47-53.

22 J.N. Kearns-Bodkin, K.E. Leonard, Alcohol involvement and marital quality in the early years of marriage: A longitudinal growth curve analysis, „Alcoholism: Clinical and Experimental Research" 2005, nr 29(12), s. 2123-2134; M.D. Newcomb, Drug use and intimate relationships among women and men: Separating specific from general effects in prospective data using structural equation models, „Journal of Consulting and Clinical Psychology" 1994, nr 62(3), s. 463-476. 
funkcjonowanie w relacjach społecznych (pozabezpieczne style więzi) predysponuje do powstawania uzależnieńn ${ }^{23}$.

Dla sprawdzenia tego posłużono się metaanalizą badań podłużnych nad przywiązaniem i uzależnieniem od substancji ${ }^{24}$. W analizie wykorzystano 34 badania longitudinalne (całkowita liczba osób badanych $\mathrm{N}=56721$ ) obejmujące przedział czasu od 1 miesiąca do 20 lat ( $\mathrm{M}=3,8$ lat). Podsumowując, wyniki tej ważnej, szerokiej i szczegółowej analizy były następujące: 1 . Osoby o pozabezpiecznym stylu przywiązania angażują się w większym stopniu w nadużywanie substancji niż osoby o bezpiecznym stylu przywiązania, 2. Występuje istotny statystycznie związek pomiędzy wcześniejszymi stylami przywiązania, a późniejszym uzależnieniem, 3. Mniej bezpieczny styl przywiązania (występujący wcześniej w czasie) poprzedza późniejszy wzrost nadużywania substancji, 4. Związek pomiędzy wcześniejszym stylem przywiązania, a późniejszym nadużywaniem substancji jest znacząco silniejszy niż pomiędzy wcześniejszym nadużywaniem substancji, a późniejszym stylem przywiązania (przywiązanie jest silniejszym predyktorem dla uzależnienia niż uzależnienie dla przywiązania). Analizy innych badaczy także potwierdzają, iż system przywiązaniowy leży u źródła uzależnień i pozabezpieczny styl przywiązania jest czynnikiem predysponującym do późniejszych uzależnień25 ${ }^{25}$

\subsection{Droga od przywiązania do uzależnienia - możliwe mechanizmy}

\subsubsection{Regulacja afektu}

Podstawową funkcją systemu przywiązaniowego jest regulacja afektu ${ }^{26}$. Osoby, które nie potrafią do regulacji emocji używać ludzi jako bezpiecznych figur przywiązaniowych, mogą dla szukania ulgi sięgać po substancje czy czynności. Zarówno w procesie przywiązania jak i uzależnienia człowiek sięga po

23 C.E. Fairbairn, J.A. Cranford, A multimethod examination of negative behaviors during couples interactions and problem drinking trajectories, „Journal of Abnormal Psychology" 2016, nr 125(6), s. 805-810.

24 C.A. Fairbairn, D. Briley, D. Kang, C. Fraley, B. Hankin, T. Ariss, A Meta-Analysis of Longitudinal Associations Between Substance Use and Interpersonal Attachment Security, „Psychological Bulletin” 2018, nr 144(5), s. 532-555.

25 J.P. Burkett, L.J. Young, L.J., The behavioral, anatomical and pharmacological parallels between social attachment, love and addiction, „Psychopharmacology” 2012, nr 224(1), s. 1-26; T.R. Insel, Is social attachment an addictive disorder? „Physiology \& Behavior" 2003, nr 79(3), s. 351-357.

26 M.L. Cooper, P.R. Shaver, N.L. Collins, Attachment styles, emotion regulation, and adjustment in adolescence, ,Journal of Personality and Social Psychology” 1998, nr 74(5), s. $1380-1397$. 
zewnętrzne środki dla regulacji afektu ${ }^{27}$. Dzieje się tak dlatego, że nie jest biologicznie możliwe, by człowiek sam regulował swój własny system nerwowy i afekt w dłuższym okresie czasu - mózg nie ma natury samo-regulacji w izolacji od świata zewnętrznego ${ }^{28}$. Niemowlęta zaczynają budować własny system regulacji afektu w oparciu o relację z rodzicem, są biologicznie zaprogramowane na szukanie i budowanie przywiązania z opiekunem. Jeśli opiekun nie jest w stanie nauczyć dziecka prawidłowej regulacji emocji w relacji z drugim człowiekiem, dziecko, gdy dorośnie, nie będzie sięgało po innych ludzi w celu samoregulacji. Jednocześnie będzie wymagało zewnętrznego źródła regulacji afektu - tę lukę bardzo szybko może wypełnić alkohol narkotyki, seks jedzenie, hazard etc.

Wykazano jednak, że związek pomiędzy pozabezpiecznym przywiązaniem a nadużywaniem substancji słabnie wraz z wiekiem osób badanych ${ }^{29}$. Badacze wyjaśniają to tym, że część badanych w dorosłym życiu sięga ma jednak różnorodne doświadczenia $w$ relacjach z ludźmi (poza rodziną pochodzenia), prawdopodobnie zmniejszając w ten sposób siłę negatywnego wpływu zaburzonych więzi w dzieciństwie, czy też siłę pozabezpiecznej więzi z jedną osobą ${ }^{30}$.

\subsubsection{Neuromechanizm}

W ostatnich latach badacze dzięki neuroobrazowaniu znaleźli neurosystem w mózgu powiązany z systemem przywiązaniowym oraz uzależnieniami. Wnioskują oni, że neurosystemy odpowiedzialne za przywiązanie pomiędzy rodzicami a dziećmi oraz pomiędzy partnerami romantycznymi są jednocześnie bazą dla powstawania procesu uzależnienia ${ }^{31}$. Kiedy przywiązanie w dzieciństwie nie jest bezpieczne, dziecko doświadcza traumy w relacji z opiekunem, co

27 G.F. Koob, M. Le Moal, Drug abuse: Hedonic homeostatic dysregulation. „Science” 1997, 278(5335), s. 52-58; J.A. Simpson, W.A. Collins, S. Tran, K.C. Haydon, Attachment and the experience and expression of emotions in romantic relationships: A developmental perspective, ,Journal of Personality and Social Psychology” 2007, 92(2), s. 355-367.

28 P.J. Flores, Addiction as an attachment disorder, Jason Aronson, New York 2004.

29 C.A. Fairbairn, D. Briley, D. Kang, C. Fraley, B. Hankin, T. Ariss, A Meta-Analysis of Longitudinal Associations Between Substance Use and Interpersonal Attachment Security, „Psychological Bulletin” 2018, nr 144(5), s. 532-555.

30 S. Madigan, L.E. Brumariu, V. Villani, L. Atkinson, K. Lyons-Ruth, Representational and questionnaire measures of attachment: A meta-analysis of relations to child internalizing and externalizing problems, „Psychological Bulletin” 2016, nr 142(4), s. 367-399.

31 J.P. Burkett, L.J. Young, L.J., The behavioral, anatomical and pharmacological parallels between social attachment, love and addiction, „Psychopharmacology” 2012, nr 224(1), s. 1-26; T.R. Insel, Is social attachment an addictive disorder? „Physiology \& Behavior" 2003, nr 79(3), s. 351-357. 
pozostawia ślady w jego mózgu, neurosystemie ${ }^{32}$ i daje długoterminowe skutki zwłaszcza w rozwoju części mózgu odpowiedzialnych za strategie radzenia sobie ${ }^{33}$. Doświadczenia zawstydzania, odrzucenia, strachu, obojętności ze strony rodzica wdrukowują się w obwody podwzgórzowe ciała migdałowatego ${ }^{34} \mathrm{i}$ są przechowywane w strukturach mózgu ${ }^{35}$. Skutkuje to chronicznym stanem aktywacji ciała migdałowatego ${ }^{36}$, podwyższonym poziomem kortyzolu ${ }^{37}$. Badacze podkreślają, że uzależnienie (podobnie jak zaburzenia więzi) polega na hyperaktywacji ośrodka nagrody w mózgu oraz zmianach $w$ systemie dopaminergicznym ${ }^{38}$. Kiedy ludzie nie mogą „,nagrodzić się" kontaktem z innymi, nagradzają się czym innym ${ }^{39}$.

Nie każdy, kto ma kontakt z daną substancją czy czynnością, będzie jej nadużywał, czynnikiem ryzyka jest neurobiologia i psychologia emocji - jednostka posiadająca zmniejszoną ilość receptorów dopaminowych z radością poszuka czegoś „,zewnętrznego" (substancji, czynności - alkoholu, narkotyków, seksu, jedzenia, zakupów etc.), co dostarczy jej dopaminy ${ }^{40}$. Specyficzne zmiany zarówno obszaru limbicznego jak i systemu dopaminergicznego są charakterystyczne

32 B. Lipton, D. Fosha, Attachment as a transformative process in AEDP: Operationalizing the intersection of attachment theory and affective neuroscience, "Journal of Psychotherapy Integration" 2011, nr 21, s. 253-279.

33 A.N. Schore, Affect dysregulation and disorders of the self, W. W. Norton \& Company, Inc., New York 2003.

${ }^{34}$ M. Wilkinson, Undoing trauma: contemporary neuroscience: A Jungian clinical perspective, „Journal of Analytical Psychology” 2003, nr 48, s. 235-253.

35 E. Ginot, Self narrative and dysregulated affective states: The neuropsychological links between self-narratives, attachment, affect, and cognition, „Psychoanalytic Psychology" 2011, nr 29, s. 59-80.

36 B. Lipton, D. Fosha, Attachment... dz. cyt.

37 P.J. Flores, Conflict and repair in addiction treatment: An attachment disorder perspective, ,Journal of Groups in Addiction \& Recovery” 2006, nr 1, s. 5-26.

38 J. Morgenstern, N. Naqvi, H. Breiter, R. Debellis, The contributions of cognitive neuroscience and neuroimaging to understanding mechanisms of behavior change in addiction, „Psychology of Addictive Behaviors” 2013, nr 27, s. 336-350; C. Caldwell, Addiction as somatic dissociation, w: Flesh of the soul: The body we work with, red. M. Heller, P. Lang, Berne, Switzerland 2001; J.P. Burkett, L.J. Young, L.J., The behavioral... dz. cyt.

39 L. Cozolino, The neuroscience of human relationships: Attachment and the developing social brain. Norton, New York 2006.

${ }^{40}$ G. Mate, In the realm of the hungry ghosts: Close encounters with addiction, North Atlantic Books, Berkley 2010. 
zarówno dla przywiązania jak i uzależnień ${ }^{41}$. Konsekwencje pozabezpiecznego stylu przywiązania w dzieciństwie takie jak: nieumiejętność budowania i utrzymywania satysfakcjonujących relacji społecznych, dysfunkcje regulacji afektu, brak spójnego obrazu siebie jako wartościowej osoby tworzą podatny grunt dla uzależnień. Ludzki mózg ze swej natury do odpowiedniego funkcjonowania i regulacji wymaga relacji z ludźmi ${ }^{42}$, dlatego zachowania uzależnieniowe są konieczne, gdy intymność w relacjach jest niemożliwa - jako jej substytut ${ }^{43}$.

Wszystkie te zmiany na poziomie mózgu dają efekt na poziomie psychologicznym - w postaci różnych problemów i zaburzeń, w tym zwłaszcza dysfunkcji regulacji afektu. Co gorsza, powstaje błędne koło - uzależnienie jest narzędziem samoleczenia, potrzebnym do wyregulowania systemu nerwowego i afektu, jednocześnie jego długoterminowy skutek jest paradoksalny - zmiany emocjonalne $\mathrm{i}$,wyregulowanie" uzyskane w ten sposób jest chwilowe, a następuje po nim dysregulacja na głębszym poziomie, co wzmacnia w jednostce potrzebę sięgania po substancje i czynności dla regulacji i głębsze uzależnianie się od nich ${ }^{44}$.

\section{Uzależnienie od seksu}

\subsection{Definicja}

Wedle obecnej klasyfikacji (ICD-11) ${ }^{45}$ większość uzależnień behawioralnych (od czynności - w tym seksoholizm) jest sklasyfikowane jako Impulse Control Disorder (Zaburzenia Kontroli Impulsów) czyli zaburzenia polegające na kompulsywnym, powtarzającym się zaangażowaniu $\mathrm{w}$ dane zachowania pomimo negatywnych konsekwencji. Istotą tych zaburzeń jest ograniczona kontrola nad zachowaniem problematycznym oraz odczuwanie impulsów nie do odparcia wraz z narastającym napięciem. Poddanie się impulsowi powoduje spadek napięcia, co daje odczucie ulgi a nawet doznania euforyczne. Na koniec osoba dotknięta tym problemem odczuwa wstyd związany z problematycznym zachowaniem i uleganiem impulsom.

${ }^{41}$ O. Morgan, Thoughts on the interaction of trauma, addiction, and spirituality, „Journal of Addictions and Offender Counseling” 2009, nr 30, s. 5-15.

42 D.J. Siegel, Pocket guide to interpersonal neurobiology: An integrative handbook of the mind, W.W. Norton \& Company Inc., New York 2012.

43 P.J. Flores, Conflict... dz.cyt.

44 N. LaFond Padykula, P. Conklin, The self regulation model of trauma and addiction, „Clinical Social Work Journal” 2010, nr 38, s. 351-360.

45 https://icd.who.int/browsel1/1-m/en\#/http://id.who.int/icd/entity/1602669465 [odczyt: 10.09.2018] 
Pierwszym, który opisał seksoholizm, zaliczając go do uzależnień, był Carnes ${ }^{46}$. Podkreślał, że istotą tego zaburzenia jest: nadmierna koncentracja wokół seksu (obsesje), impulsywność oraz utrata kontroli nad zachowaniem (kompulsje) oraz uczucie wstydu. W swych behawioralnych przejawach uzależnienie takie polega na nadmiernej masturbacji, seksie bezosobowym, rozhamowanych zachowaniach seksualnych.

$\mathrm{Na}$ przestrzeni lat zaproponowano kolejnych 100 definicji seksoholizmu ${ }^{47}$, w tym impulsywność seksualna ${ }^{48}$, kompulsywność seksualna ${ }^{49}$, hiperseksualizm ${ }^{50}$ oraz najobszerniejszy out-of-control sexual behaviour (zachowanie seksualne poza kontrolą, OCSB) ${ }^{51}$.

Uzależnienie od seksu powstaje, gdy człowiek używa seksu do radzenia sobie ze złością, lękiem, samotnością, stresem, do relaksu, do potwierdzania siebie (i swojej wartości), do niszczenia (siebie, innych ludzi, swoich związków). Jest to uzależnienie postrzegane jako jedno z grupy uzależnień behawioralnych, czyli takich, w których występuje zespół objawów związanych z utrwalonym, wielokrotnym powtarzaniem określonej czynności (lub grupy czynności) w celu uzyskania określonych emocjonalnych (zmiany nastroju). W uzależnieniach behawioralnych występuje czynność (zakupy, jedzenie, seks) w miejsce substancji zewnętrznych (alkohol, narkotyki).

W przypadku seksoholizmu sytuacja jest o tyle bardziej skomplikowana, że ekstaza płynąca z aktywności seksualnej i orgazmu wiąże się ze znacząco zwiększonym wydzielaniem endorfin (peptydy o budowie identycznej jak opiatów takich jak np. morfina, heroina ale wiele od nich silniejsze). Gwałtowny napływ endorfin do centralnego układu nerwowego daje uczucie euforii i można je nazwać własną,

46 P. Carnes, Contrary to love: Helping the sexual addict, CompCare, Minneapolis 1989.

47 G.B. O'Donohue, Out of control sexual behavior: An analysis of various authors' attempts to operationalize a construct, Unpublished masters' thesis, Harvard University, Cambridge 2001.

48 R.J. Barth, B.N. Kinder, The mislabelling of sexual impulsivity, „Journal of Sexual \& Marital Therapy" 1987, nr 13(1), s. 15-23.

49 E. Coleman, Is your patient suffering from compulsive sexual behaviour? „Psychiatric Annals" 1992, nr 22, s. 320-325.

50 R. Reid, B.N. Carpenter, T.Q. Lloyd, Assessing psychological symptom patterns of patients seeking help for hypersexual behavior, „Journal of Sexual \& Relationship Therapy” 2009, nr 24(1), s. 47-63.

51 J. Bancroft, Z. Vukadinovic, Sexual addiction, sexual compulsivity, sexual impulsivity, or what? Toward a theoretical model, „Journal of Sexual Research” 2004, nr 41, s. 225-234. 
wewnętrzną intoksykacją. Można zatem powiedzieć, że seks działa jak narkotyk, a seksoholik stale nosi w sobie potencjalny jego zapas wywoływany kolejnymi aktami seksualnymi. Goodman ${ }^{52}$ opisując cykl charakterystyczny dla uzależnienia od seksu (impulsy - wzrost napięcia -uleganie impulsom - spadek napięcia - ulga, euforia) podkreśla, że uczucie euforyczne, przyjemność, jaką daje uzależnienie seksualne bardziej nawiązuje do uzależnienia od substancji niż behawioralnego.

W sytuacji silnego zauroczenia i fascynacji nową osobą substancja o nazwie PEA (fenyloetyloamina) odpowiada za chemię miłości, zalotów, uniesień w trakcie silnego przeżywania atrakcyjności nowo poznanej osoby ${ }^{53}$. PEA daje efekt gwałtownej uczuciowej ekstazy, zmienia nastrój w nagły sposób (choć krótkotrwale). W eksperymencie, w którym wstrzyknięto PEA małpom, zaczęły one przejawiać zachowania hiperseksualne ale tylko, jeśli były w obecności osobników przeciwnej płci. Im dłużej trwa związek romantyczny dwojga ludzi, tym bardziej poziom tej substancji w organizmie maleje. Jest o wiele więcej związków chemicznych zawiadujących w mózgu seksualnymi i miłosnymi uniesieniami oraz silną potrzebą ciągłego ich poszukiwania (przykładowo epinefryna). Mimo że uzależnienie od seksu jest uzależnieniem behawioralnym, można uznać, że seks (oraz zauroczenie) jest jednocześnie niezmiernie silnym narkotykiem, który seksoholik może autonomicznie wyprodukować.

Po czym poznać czy dana osoba jest uzależniona od seksu? Występuje kilka głównych oznak tego nałogu ${ }^{54}$ :

- Utrata kontroli nad zachowaniami seksualnymi (liczba, zasięg przekracza wyznaczane sobie granice),

- Negatywne konsekwencje zachowań seksualnych (podejmowanie ryzykownych zachowań seksualnych, niedbanie o własne bezpieczeństwo, w tym konsekwencje związane z ciążą, HIV, chorobami wenerycznymi, aborcją, zniszczeniem małżeństwa i relacji z dziećmi, kariery i relacji zawodowych, doprowadzenie do skrajnego wyczerpania swojego organizmu, podejmowanie zachowań niezgodnych z obowiązującym prawem),

- Niemożność zaprzestania mimo wszechogarniających negatywnych konsekwencji (uzależnienie silniejsze niż ponoszone kolejne konsekwencje, poczucie przymusu uprawiania seksu i braku wpływu,

52 A. Goodman, Addiction: definition and implications, „British Journal of Addiction” 1990, nr 85(11), s. 1403-1408.

53 M. Liebowitz, The chemistry of love, Liitle, Brown, \&Co, Boston 1983.

54 P. Carnes, Od nałogu do miłości, Media Rodzina, Poznań 2001. 
- Poszukiwanie sytuacji ryzykownych i podejmowanie zachowań autodestrukcyjnych (postępowanie narażające siebie na wysokie ryzyko - choroby, przemocy, więzienia, śmierci, prowokowanie zagrożeń),

- Podejmowanie prób kontrolowania seksu w wyniku poczucia winy (zaprzestania, ograniczenia, co prowadzi tylko do naprzemiennego cyklu blokowania/hamowania i utraty kontroli; szukanie zewnętrznych gwarantów zmiany przy małej sile wewnętrznej by zmiany dokonać - takich jak religia, zmiana pracy, miejsca zamieszkania, pójście do wojska, zmiana samochodu by w nowym utrudnione było uprawianie seksu),

- Obsesyjne fantazje seksualne i używanie seksu jako głównej strategii życiowej (nadmierne zaabsorbowanie seksem, uporczywe obsesyjne myśli o treści seksualnej i kompulsywne czynności natury seksualnej, używanie myśli i zachowań seksualnych jako jedynych możliwych reakcji na każdą emocję, sytuację życiową, problem; planowanie zdobycia kolejnej partnerki/ partnera, intrygi i fantazje wypełniają treścią każdy dzień; fantazje i obsesje dające własny wewnętrzny „haj”, zatracanie własnego ,ja” w obsesji, zachowania typu „acting out” - redukowanie poziomu napięcia i lęku zachowaniami seksualnymi dającymi silne odreagowanie i upust emocji),

- Zwiększanie intensywności doznań seksualnych (habituacja - przyzwyczajenie do znanego bodźca, potrzeba silniejszych bodźców by uzyskać pobudzenie czy ulgę),

- Głębokie zmiany osobowości (podwójne życie, wstyd, nienawiść do siebie, cierpienie, bezsilność, brak kontroli, jednocześnie poczucie bycia kimś wyjątkowym, posiadającym niezwykłe życie, jednocześnie nieuleczalnym, zaburzenia wynikające $\mathrm{z}$ łączenia tych skrajności: wyjątkowość vs nienormalność, wstyd vs zadowolenie/przyjemność, trudności w oddzieleniu lęku od podniecenia, wstydu od aktu seksualnego, leczenie bólu życiem na krawędzi i ryzykiem, działanie zgodnie z własnym poczuciem bezwartościowości - poczucie, że nie zasługuje na nic więcej a seks musi być czymś złym i upodlającym),

- Organizacja życia codziennego podporządkowana uzależnieniu (wszystko podporządkowane obsesjom i zachowaniom seksualnym, zaniedbywanie reszty swojego życia, całe życie według cyklu: fantazje - uwodzenie inicjowanie seksu - uprawianie seksu - poczucie winy i kac moralny radzenie sobie z konsekwencjami nałogu),

- Zaniedbywanie spraw zawodowych, rodzinnych (stopniowa utrata innych zainteresowań, znajomości, rodziny, pracy). 
Bancroft i Vukadinovic ${ }^{55}$ postulują, by mieć świadomość różnorodności typów niekontrolowanych zachowań seksualnych (out-of-control sexual behaviors- OCSB) i nie używać jedynie określenia „uzależnienie”, ponieważ różne nieuregulowane zachowania seksualne mogą mieć bardzo różne etiologie. Badacze ci wymieniają kilka mechanizmów wyodrębnionych w swoich badaniach nad problematycznymi zachowaniami seksualnymi: zaburzenia afektu (lęk, depresja), przyczyny neurobiologiczne, dysfunkcje mechanizmów samoregulacji afektu (samouspokajanie się poprzez seks), dysfunkcje regulacji systemu nagrody (orgazm wzmacnia OCSB). Te hipotezy nie zostały potwierdzone w innych badaniach - poza etiologią związaną z regulacją afektu i samoregulacją oraz trudnościami w relacjach z ludźmi ${ }^{56}$. Reid ${ }^{57}$ w swoim badanu 120 osób hiperseksualnych wykazała wśród nich większą (niż w grupie kontrolnej) niestabilność emocjonalną, podatność na stres, trudności w identyfikowaniu emocji. Opisane dysfunkcje naturalnie wydają się badaczom naprowadzać na trop wczesnych doświadczeń przywiązaniowych jako źródła OCSB.

\section{Dom rodzinny a uzależnienie od seksu}

\subsection{Cechy domu rodzinnego}

Według Erika Eriksona ${ }^{58}$ pierwsza faza rozwoju dziecka (trwająca w relacji $\mathrm{z}$ matką w ciągu pierwszego roku życia dziecka) polega na budowaniu się w nim podstawowej nieufności lub ufności (kształtowaniu nadziei) na resztę jego życia. Druga faza z kolei (do 3 roku życia) buduje w dziecku wstyd (niepewność, konieczność polegania na innych, bycia zależnym) lub autonomię (wolę, poczucie kompetencji, sprawstwa). Uczuciem wiodącym w powstawaniu i wznawianiu się uzależnienia jest właśnie wstyd połączony z nieufnością. By zbudować jednostkę niepodatną na uzależnienia rodzice $\mathrm{w}$ pierwszych 3 latach życia dziecka powinni przede wszystkim być dla dziecka bezpieczną bazą (kształtowanie ufności) oraz wspierać je w ćwiczeniu własnych kompetencji (dodawać odwagi, adekwatnie

55 J. Bancroft, Z. Vukadinovic, Sexual... dz. cyt.

56 Tamże; R. Reid, B. Carpenter, M. Spackman, D. Willes, Alexithymia, Emotional Instability, and Vulnerability to Stress Proneness in Patients Seeking Help for Hypersexual Behavior, „Journal of sex \& marital therapy” 2008, nr 34, s. 133-49; L. Cozolino, The neuroscience... dz. cyt.; K. Creeden, The Neurodevelopmental Impact of Early Trauma and Insecure Attachment: Re-Thinking Our Understanding and Treatment of Sexual Behavior Problems, „Sexual Addiction \& Compulsivity” 2004, nr 11(4), s. 223-247.

57 R. Reid, B. Carpenter, M. Spackman, D. Willes, Alexithymia ... dz. cyt.

58 E.H. Erikson, The life cycle completed, W.W. Norton, New York 1982. 
oceniając, co dziecko już potrafi). Osoby uzależnione, w dzieciństwie doświadczały częstego zawstydzania (uczucia, dążenia, potrzeby i własna wola dziecka są nieakceptowalne). Zarówno nadmierne oczekiwania jak i brak oczekiwań jest nieakceptowaniem tego, kim dziecko jest, jakie jest, czego potrzebuje i doświadcza. Nadmierne oczekiwania i wysokie wymagania budują w dziecku perfekcjonizm, przymus bycia doskonałym (przy jednoczesnym poczuciu - nigdy nie jestem dość dobry). W dorosłym życiu takie osoby najczęściej dążą do coraz większych osiągnięć, podnosząc sobie ciągle poprzeczkę, myśląc, że zasłużą na miłość, uwagę, gdy będą jeszcze lepsze, a w głębi czują lęk, że ciągle nie są dość dobrzy. Ich życiem kieruje presja, stres, porównywanie się z innymi. Rygorystyczne rodziny budują wstyd na punkcie własnej osoby i trudną do sprostania obsesję kontroli. Uzależnienie od seksu jest odbiciem ich sytuacji - daje możliwość puszczenia kontroli i nieustannego przeżywania wstydu.

W rodzinach takich miłość jest warunkowa, gdy dziecko spełni wysokie oczekiwania, ma nadzieję na aprobatę ze strony rodziców (a jest ona wyrażana bardzo rzadko). Opinię o sobie dziecko buduje na podstawie opinii innych ludzi o nim (i w nieskończoność szuka aprobaty innych). Czuje, że nigdy nie jest dość dobre, akceptowanie, wartościowe. Najczęściej rodzice nieakceptujący swoich dzieci takimi jakie są (bezwarunkowo), stawiający wymagania i reguły do spełnienia (warunki) kierują się lękiem przed bliskością. Dodatkowo uczą dzieci, by nie okazywały swoich emocji, zwłaszcza tych dla rodzica niewygodnych jak lęk, złość, smutek (zgodnie z zasadą ,nie kołysz łódką"). Trudne sprawy w rodzinie nie są poruszanie, a uwaga wszystkich jest koncentrowana na zachowaniach, osiągnięciach, celach. Łamanie dziecięcych granic (zmuszaniem, nakazami, bezwzględnymi regułami, nieliczeniem się z nim) uczy go także, że inni ludzie mogą nie szanować jego granic i on sam może ich nie ustanawiać (powinienem innym dawać wszystko, czego potrzebują, nie odmawiać, w tym także seksu).

Akceptowanie dzieci takimi, jakie są, pomaganie im w realizacji ich potrzeb i regulowaniu emocji (także przez wyznaczanie reguł, zasad, granic i realistycznych oczekiwań) buduje jednostki zdrowe i potencjalnie mniej podatne na uzależnienia. Ludzie pełni deficytów („dziur”) z dzieciństwa próbują je zalepiać kompulsywnymi zachowaniami dającymi upust ich emocjom, wyzwalającymi i poprawiającymi (na krótko) samopoczucie. W ten sposób wchodzą w trwały cykl naprzemiennej kontroli i perfekcjonizmu (znanych z domu), po której następuje spiętrzenie bólu, tłumionych emocji, które zalewają i prowadzą do uwolnienia i rozhamowania (upragniona utrata kontroli). Naprzemienne przekazy jakie kierują zachowaniami osoby w tym cyklu to „być doskonałym” oraz „poczuć ulgę” (Rys. 1). 


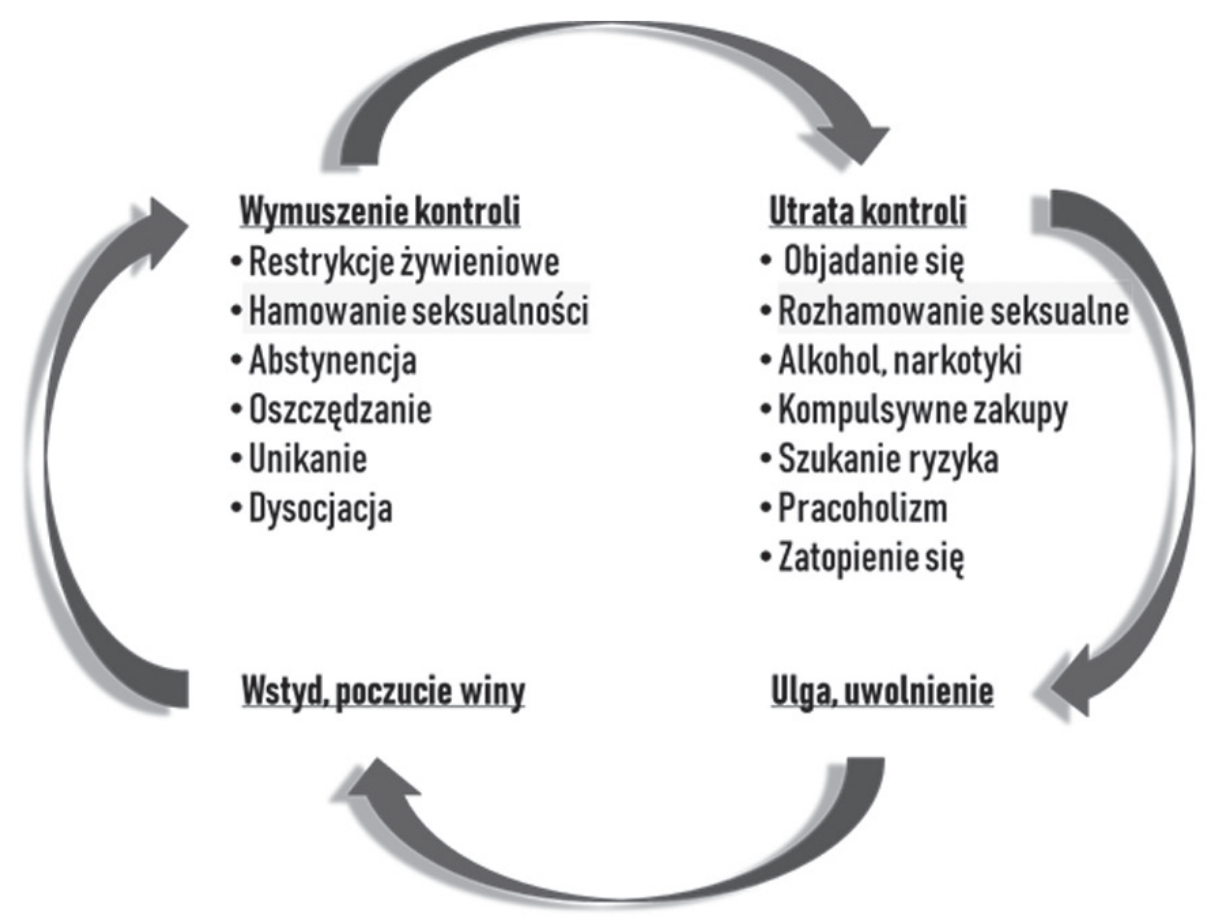

Rys. 1. Cykl uzależnienia od seksu

\subsection{Teoria wstydu (shame theory)}

Wielu autorów opisuje wstyd jako najważniejszą emocję w cyklu uzależnienia od seksu ${ }^{59}$. Wstyd jest także charakterystyczny dla wychowania w rodzinach z pozabezpiecznym stylem przywiązania. Chroniczne zawstydzanie dzieci sprawia, że są one podatne na uzależnienie od seksu, ponieważ osoba, która czuje się mało wartościowa szuka rekompensaty. Seks może stać się taką rekompensatą - uwodzenie, adorowanie i bycie obiektem zainteresowania seksualnego oraz gratyfikacja seksualna podnoszą krótkotrwale samoocenę i samopoczucie, a jednocześnie utrata kontroli nad zachowaniami seksualnymi pozwala nadal czuć wstyd ${ }^{60}$. Wstyd

59 K.M. Adams, D.W. Robinson, Shame reduction, affect regulation, and sexual boundary development: Essential building blocks of sexual addiction treatment, „Sexual Addiction \& Compulsivity" 2001, nr 8, s. 23-44; P. Carnes, Od nałogu... dz. cyt.; R. Gilliland, M. South, B. Carpenter, S. Hardy, The Roles of Shame and Guilt in Hypersexual Behavior, „Sexual Addiction \& Compulsivity” 2011, nr 18(1), s. 12-29; J.P. Schneider, B.H. Schneider, B. H., Sex, lies, and forgiveness: Couples speaking out on healing from sex addiction, Recovery Resources Press, Tucson 2004.

60 R. Gilliland, M. South, B. Carpenter, S. Hardy, The Roles... dz. cyt. ; R.C. Reid, J.M. Harper, J.H. Anderson, Coping strategies used by hypersexual patients to defend 
przejawia się poprzez 4 główne grupy przekonań obecne u osób uzależnionych od seksu, które, zdaniem tych autorów, wynikają z zinternalizowanych w dzieciństwie przekonań (i są prawdopodobnie odbiciem wewnętrznych roboczych modeli u osób z pozabezpiecznym stylem przywiązania):

1. „Jestem zły i nic nie wart” ${ }^{\text {, }}$, co często zostało zinternalizowane w dzieciństwie. Jeśli rodzice zaniedbują czy źle traktują dzieci (pozabezpieczny styl przywiązania), te, wierząc, iż rodzic jest istotą idealną i nie byłby zdolny do krzywdzenia, obwiniają siebie ${ }^{62}$.

2. "Gdyby inni poznali, jaki jestem naprawdę, nie pokochali by mnie"63 powinno się zatem ukryć prawdziwe „Ja” aby uniknąć porzucenia czy odrzucenia ${ }^{64}$.

3. „Inni ludzie nie odpowiedzą na moje potrzeby”65, co wynika z doświadczenia w dzieciństwie tego, iż rodzic nie odpowiadał na potrzeby dziecka, zatem nie można mu było zaufać (ludziom nie wolno ufać a świat nie jest bezpieczny) ${ }^{66}$.

4. „Seks jest najważniejszy w hierarchii potrzeb człowieka"67, co wynika $\mathrm{z}$ tego, że rodzice nie odpowiedzieli na potrzeby dziecka i zostało ono $\mathrm{z}$ bardzo silnym głodem bliskości i dorasta w pewnej obsesji tej potrzeby i zniewoleniu nią i próbują ją zaspokoić za wszelką cenę ${ }^{68}$.

5. Te przekonania (wewnętrzne robocze modele), mające swoje źródło w dzieciństwie, leżą u źródła zachowań seksualnych osób z pozabezpiecznym stylem przywiązania ${ }^{69}$. Seks staje się jednocześnie adaptacją do tej trudnej sytuacji oraz mechanizmem obronnym, utrzymującym problem (potwierdzającym zwrotnie te przekonania) ${ }^{70}$.

against the painful effects of shame, „Clinical Psychology \& Psychotherapy” 2009, nr 16(2), s. 125-138.

$61 \quad$ P. Carnes, Od nałogu... dz. cyt.

62 M.C. Ferree, No Stones: Women Redeemed from Sexual Addiction, InterVarsity Press 2010.

63 P. Carnes, Od nałogu... dz. cyt.

64 M.C. Ferree, No Stones... dz. cyt.

65 P. Carnes, Od nałogu... dz. cyt.

66 M.C. Ferree, No Stones... dz. cyt.

67 P. Carnes, Od nałogu... dz. cyt.

68 M.C. Ferree, No Stones... dz. cyt.

69 K.M. Adams, D.W. Robinson, Shame reduction, affect regulation, and sexual boundary development: Essential building blocks of sexual addiction treatment, "Sexual Addiction \& Compulsivity" 2001, nr 8, s. 23-44.

70 M.C. Ferree, No Stones... dz. cyt. 


\section{Uzależnienie od seksu a teoria przywiązania}

Teoria przywiązania podkreśla, jak ważne jest budowanie bezpiecznej, intymnej relacji z opiekunem we wczesnych latach życia dziecka. Badania longitudinalne z obszaru neuronauki potwierdzają, jak silnie te wczesne doświadczenia relacyjne wpływają na rozwój mózgu oraz to, czy człowiek będzie zdolny do intymności $\mathrm{w}$ relacjach z ludźmi ${ }^{71}$. Bezpieczny styl przywiązania buduje struktury w mózgu oraz wzorce behawioralne umożliwiające w dalszym życiu budowanie intymności w relacjach koniecznej do budowania zdrowych relacji seksualnych ubogacających życie, a nie zubożających je $\mathrm{e}^{72}$. Z kolei styl pozabezpieczny sprawia, że osiągnięcie celów rozwoju psychoseksualnego, jakimi są: integracja emocjonalno-popędowa, harmonijne włączenie potrzeby seksualnej i sposobów jej realizacji w całość swojej tożsamości i swojego życia, osiągnięcie dojrzałości psychoseksualnej czyli zdolności do funkcjonowania w intymnym, satysfakcjonującym dla obydwu stron związku z drugim człowiekiem, nie jest możliwe ${ }^{73}$. Wedle badań pozabezpieczny styl przywiązania rodzi takie konsekwencje jak: problemy z regulacją emocjonalną, empatią, dostrajaniem się do ludzi, kontrolą impulsów, samoukojeniem i samoświadomością, nadmierne pobudzenie emocjonalne lub odcięcie ${ }^{74}$. Zdaniem Creedena ${ }^{75}$ te umiejętności są kluczowe dla rozwijania odpowiedzialnych zachowań seksualnych w życiu dorosłym. Badania potwierdzają, że osoby z OCSB mają

71 L. Cozolino, The neuroscience... dz.cyt.; A. Katehakis, Sex addiction as affect dysregulation, W. W.

Norton \& Company Inc., New York 2017, s. 119-124; G. Hudson-Allez, Infant losses; Adult searches: A neural and developmental perspective on psychopathology and sexual offending, Karnac Books, London 2009;

J.H. Obegi, E. Berant, Attachment theory and research in clinical work with adults, The Guilford Press, New York 2009; A.N. Schore, Effects of a secure attachment on right brain development, affect regulation, and infant mental health. „Infant Mental Health Journal” 2001, nr 22, s. 27-35; D.J. Siegel, Pocket... dz. cyt.; A. Sroufe, Attachment and development: A prospective, longitudinal study from birth to adulthood, „Journal of Attachment and Human Development" 2005, nr 7, s. 349-367.

72 J.H. Obegi, E. Berant, Attachment... dz. cyt.

73 K. Creeden, The Neurodevelopmental... dz. cyt.; A. Sroufe, Attachment... dz. cyt.

74 L. Cozolino, The neuroscience... dz. cyt.; G. Hudson-Allez, Infant... dz. cyt.; A.N. Schore, Effects... dz. cyt.; D.J. Siegel, Pocket... dz. cyt.

75 K. Creeden, The Neurodevelopmental... dz. cyt. 
wyższe wskaźniki pozabezpiecznego stylu przywiązania w dorosłym życiu ${ }^{76}$, zależność ta jest znacząco silniejsza w grupie kobiet ${ }^{77}$.

Richard Leedes ${ }^{78}$ jako pierwszy w swoim badaniu na niewielkiej grupie klinicznej (22 osoby) osób uzależnionych od seksu sprawdził, iż osoby te prezentują pozabezpieczny styl przywiązania (68\% styl unikający, a 27\% styl ambiwalentny) oraz wyraźnie przejawiają większy dyskomfort związany z bliskością niż osoby z grupy kontrolnej. Leedes opisał także ciekawe zjawisko dotyczące fantazji u osób uzależnionych od $\operatorname{seksu}^{79}$. Zdaniem tego badacza depersonalizowane fantazje seksualne, będące ważnym elementem uzależnienia od seksu, wywodzą się z wewnętrznych roboczych modeli. Głównym zadaniem procesu przywiązania jest stworzyć bliską relację z obiektem, zdaniem Leedesa w przypadku dzieci z pozabezpiecznym stylem przywiązania wytwarza się bliska relacja jedynie w świecie fantazji (w rzeczywistym - z ich rodzicem - nie była możliwa). W efekcie tego osoba taka w dorosłym życiu tworzy fantazje (seksualne), w których najważniejsze jest uprzedmiotowienie (siebie lub kogoś lub obojga). Siła wpływu tych fantazji słabnie, im silniejsze przywiązanie zbudują z realnym człowiekiem w swoim życiu ${ }^{80}$. Jest związek pomiędzy poziomem uprzedmiotowienia $w$ tych fantazjach (i ich zdepersonalizowaniem) a pozabezpiecznym przywiązaniem - im bardziej przywiązanie staje się bezpieczne, tym bardziej ilość i siła fantazji maleje.

\section{Społeczne tlo uzależnienia od seksu}

\subsection{Społeczne tło uzależnień}

Uzależnienie buduje się na wielu różnych podłożach. Pierwszym z nich jest tło społeczne - cywilizacja i kultura, w której żyjemy. Jest to kultura konsumpcyjna,

76 A.F., Bogaert, S. Sadava, Adult attachment and sexual behavior, "Personal Relationships" 2002, nr 9, s. 191-204; A.L. Gentzler, K.A. Kerns, Associations between insecure attachment and sexual experiences, "Personal Relationships" 2004, nr 11, s. 249265; R. Leedes, Theory and praxis: A heuristic for describing, evaluating, and intervening on sexual desire disorders when sexual expression interferes with humanistic expression, "Journal of Sexual Addiction \& Compulsivity" 1999, nr 6, s. 289-310; J.L. Zapf, J. Greiner, J. Carroll, Attachment styles and male sex addiction, "Journal of Sexual Addiction \& Compulsivity" 2008, nr 15, s. 158-175.

77 K. Faisandier, J. Taylor, R. Salisbury, What does attachment have to do with out-of-control sexual behaviour? „New Zealand Journal of Psychology” 2011, nr 40(3), s. 19-29.

78 R. Leedes, Theory... dz. cyt.

79 Tamże

80 Tamże 
ludzie nastawieni są na szybkie zaspokajanie swoich potrzeb, są mało odporni na frustrację, nie potrafią odraczać gratyfikacji. Większość otaczającego nas świata jest tak skonstruowana, by szybko i bez wysiłku zaspokajać ludzkie zachcianki i budować w ludziach wiarę w dostępność i wartość łatwych rozwiązań (stąd jako przeciwwaga rodząca się powoli koncepcja slow life).

W takiej codzienności ludzie gubią też umiejętności nadawania sensu życiu, szukania znaczeń, głębi. Wszystko co nas otacza ma dostarczać lekkiej i łatwej rozrywki, nie obarczać filozofią. Po pracy wszyscy chcą się oderwać od rzeczywistości, a nie rozmyślać (stąd popularność miałkich programów telewizyjnych, czasopism z plotkami o gwiazdach itp.). Buduje to poczucie braku głębszego sensu życia, dominuje szukanie rozrywki i ucieczki.

System tradycyjnych wartości jest przez rzeczywistość nieustannie podważany. W rzeczywistości przełomów technologicznych, gdzie niemożliwe staje się możliwe, tradycyjne wartości nie nadążają za rzeczywistością jaka nas otacza. W świecie, w którym możliwa i dostępna jest coraz bardziej zaawansowana kontrola narodzin, inżynieria genetyczna, technika komputerowa, to człowiek wyrasta w poczuciu, że można wszystko, nie ma granic, zasad.

Kolejnym społecznym obciążeniem jest rozpad rodziny, który staje się regułą, a nie wyjątkiem. Żyjemy w kulturze, która nie wspiera małżeństw w radzeniu sobie z trudnościami, tylko daje łatwe i szybkie rozwiązanie - rozstanie. Wszystkie małżeństwa przechodzą przez kryzysy i tak było od zarania dziejów, jednak współcześnie coraz gorzej radzą sobie z tymi problemami, na które nakłada się wcale niełatwa rzeczywistość, której trzeba codziennie sprostać. W epoce intensywnej pracy zawodowej kobiet nadal nie rozwiązaliśmy zagadnienia podziału domowych obowiązków i opieki nad dziećmi. Tak ważny temat jak równowaga życia zawodowego i osobistego jest obecnie jednym z najintensywniej badanych, a rozwiązań ciągle brak. W sytuacji niekończącej się walki o pogodzenie pracy zawodowej i życia rodzinnego ludzie nie mają już czasu na rozwój więzi z innymi przyjaciółmi, sąsiadami, dalszą rodziną. Kryzysowa sytuacja rodziny i relacji społecznych najczęściej owocuje rozpadem więzi.

Codzienne życie jest naszpikowane stresem. Żyjemy w cywilizacji przeładowania informacjami, bodźcami, wyzwaniami, zadaniami. W szkole, pracy buduje się atmosferę rywalizacji i wyścigu w drodze do coraz większych osiągnięć. To cywilizacja ciągłego niezaspokojenia, sięgania po więcej i stałego poczucia nie bycia jeszcze dość dobrym (inni są lepsi). Na takim gruncie nie budujemy w ludziach empatii, troski o los innych ludzi, tylko nieufność i cynizm. Na czele stawki wszyscy są piękni, młodzi i bogaci, zaplanowali i zrealizowali swoje cele. Niewiele mówi się o tym, że życie bywa nieprzewidywalne, a na każdego (bez 
wyjątku) za rogiem może czekać śmierć. Jest to kultura zaprzeczająca ograniczeniom, a podkreślająca możliwości.

Wszystkie wymienione elementy naszej cywilizacji promują cechy charakterystyczne dla uzależnienia: szukanie szybkiego zaspokojenia, łatwych rozwiązań, poczucie braku sensu w życiu, rozpadu wartości, opuszczenia i izolacji, braku granic, odczucia lęku, nieufności. Dodatkowo w społeczeństwie, gdzie tak wiele osób jest uzależnionych lub funkcjonuje na granicy uzależnienia zachowania uzależnieniowe stają się normą (nie odstaję od ludzi, którzy mnie otaczają).

Dodatkowo jest to kultura rozhamowująca seksualnie. Seks jest wykorzystywany w reklamach dla zwiększenia sprzedaży (znane powiedzenie marketingowców „sex sells”, czyli lepiej sprzedaje się produkt, który będzie budził skojarzenia o treści erotycznej). Jako wartościowe postrzegane są osoby, które są atrakcyjne (seksualnie). Bogate (i rozhamowane) życie seksualne często jest postrzegane jako atut, cecha osób odważnych, wyzwolonych, pewnych siebie. Założenia przemian społecznych być może były konstruktywne - uwolnić ludzi od zahamowań, potępienia ciała i seksualności, nauczyć pary rozmawiać bez zahamowań o swoim życiu erotycznym, wspierać prawidłowy rozwój seksualny. Jednak celem rozwoju psychoseksualnego powinna być integracja emocji, popędów i więzi, harmonijne włączenie potrzeby seksualnej i sposobów jej realizacji w całość swojej tożsamości i swojego życia. Człowiek dojrzały psychoseksualnie to osoba zdolna do funkcjonowania $\mathrm{w}$ intymnym związku $\mathrm{z}$ drugim człowiekiem i zaspokajająca swoje potrzeby emocjonalne i seksualne w relacji satysfakcjonującej dla obu stron. Wypaczone rozumienie idei nieskrępowanego rozwoju seksualnego (bez elementu harmonijnego rozwoju emocjonalnego i umiejętności budowania więzi z drugim człowiekiem) prowadzi do kompulsywnych, rozhamowanych zachowań seksualnych i uzależnienia od seksu. Tu znów wracamy do idei problemów z budowaniem więzi jako podstawowych dla powstawania uzależnienia.

\subsection{W kierunku uzależnienia od seksu nowej generacji}

Paula Hall w swoich badaniach przeprowadzonych na terenie Wielkiej Brytanii wykazała, że u podłoża uzależnienia od seksu leżą trzy główne czynniki ${ }^{81}$ :

1. doświadczenie traumy,

2. pozabezpieczny styl przywiązania,

3. łatwy dostęp do okazji $(29,1 \%)$.

81 P. Hall, A New Classification Model for Sex Addiction, „Sexual Addiction \& Compulsivity" 2013, nr 20, s. 279-291. 
Postuluje ona by odejść od koncentracji na trudnych doświadczeniach w dzieciństwie jako głównych przyczynach, a poznać lepiej przyczyny społeczne. Nie ulega wątpliwości, że obecność bodźców jest we współczesnym świecie społecznym wszechobecna (bardziej niż kiedykolwiek w przeszłości). Rozwój internetu sprawił, że wszyscy ludzie mają łatwy dostęp do pornografii czy potencjalnych partnerów seksualnych. W erze smartfona dostęp ten zwiększył się wielokrotnie. Dodatkowo przemiany społeczne w zakresie norm związanych z seksualnością też ułatwiają podejmowanie zachowań seksualnych ${ }^{82}$. Dostępność seksu online, pornografii oraz interaktywność kontaktu z ludźmi poprzez telefon czy komputer może być uzależniająca i prowadzić do uzależnienia od cybersksu ${ }^{83}$. W obliczu tych przemian technologicznych i społecznych być może także profil osoby uzależnionej od seksu ulega zmianie.

Hall na podstawie swoich badań stworzyła nowy model uzależnienia od seksu zwany OAT (Oppurtunity-Attachment-Trauma, Rys. 2). Według niej istnieją cztery podstawowe etiologie zachowań seksualnych o cechach uzależnienia: trauma w dzieciństwie, pozabezpieczny styl przywiązania, okazja oraz etiologia mieszana: trauma i styl przywiązania. W każdej z tych kategorii jest dodatkowo obowiązkowo obecny ważny czynnik okazji, łatwego dostępu, ponieważ bez tego czynnika nie mówilibyśmy o uzależnieniu.

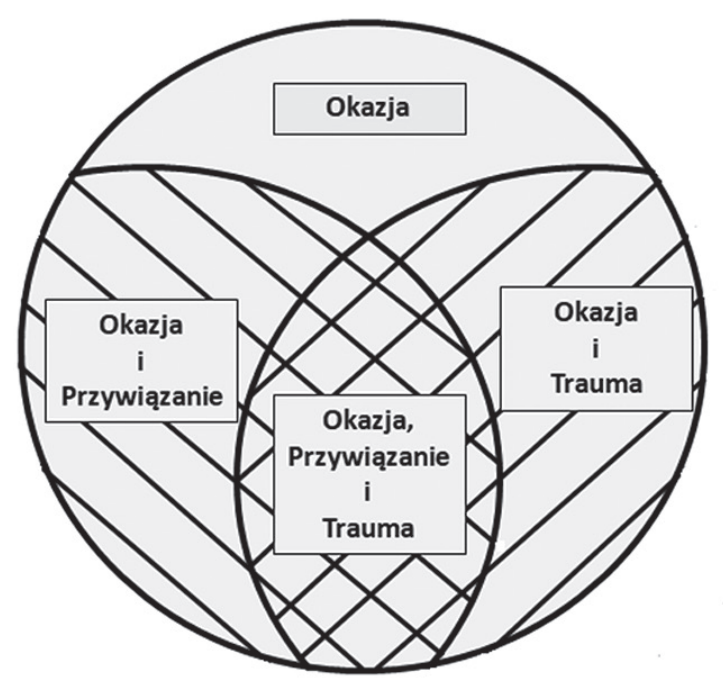

Rys. 2. Model OAT

82 J. Riemersma, M. Sytsma, A New Generation of Sexual Addiction, „Sexual Addiction \& Compulsivity: The Journal of Treatment \& Prevention" 2013, nr 20(4), s. 306-322.

83 K.S. Young, Internet sex addiction: Risk factors, stages of development, and treatment, „American Behavioral Scientist” 2008, nr 52, s. 21-37. 
Nowa rzeczywistość społeczna jest taka, że „okazja” jest wszędzie i wszyscy ludzie (bez względu na ich doświadczenia w dzieciństwie) łatwo mogą ulec eksperymentowaniu z pożądaniem, pobudzeniem erotycznym, seksem bezosobowym, cyberseksem, pornografią, zwiększaniem siły bodźców seksualnych - wystarczy kliknąć i dać się wciągnąć w wirtualny świat ${ }^{84}$. Dostępność i różnorodność bodźców silnie pobudzających seksualnie wyzwala w ludziach dwie główne potrzeby: poszukiwania przyjemności (pobudzanie ośrodka nagrody w mózgu) oraz reprodukcyjną ale ponad poziom ewolucyjnie naturalny. Wydaje się, że o ile do tej pory w grupie ryzyka uzależnienia (w tym uzależnienia od seksu) były głównie osoby z trudnym dzieciństwem, o tyle w obecnej rzeczywistości społecznej wszyscy jesteśmy w grupie ryzyka, a całe otoczenie staje się wielką kulturą uzależnień.

\section{Bibliografia}

Adams K.M., Robinson D.W., Shame reduction, affect regulation, and sexual boundary development: Essential building blocks of sexual addiction treatment, „Sexual Addiction \& Compulsivity” 2001, 8, s. 23-44.

Bancroft J., Vukadinovic Z., Sexual addiction, sexual compulsivity, sexual impulsivity, or what? Toward a theoretical model, „Journal of Sexual Research” 2004, 41, s. 225-234.

Barrett D., Supernormal stimuli-How primal urges overran their evolutionary purpose, W. W. Norton, New York: 2010.

Barth R.J., Kinder B.N., The mislabelling of sexual impulsivity, ,Journal of Sexual \& Marital Therapy" 1987, 13(1), s. 15-23.

Benfield J., Secure attachment: an antidote to sex addiction? A thematic analysis of therapists' experiences of utilizing attachment-informed treatment strategies to address sexual compulsivity, „Sexual Addiction and Compulsivity” 2018, 25(1), s. 12-27.

Benfield J., Sex addiction: the search for a secure base, „Healthcare Counselling \& Psychotherapy Journal" 2018, s. 14-17.

Bogaert A.F., Sadava S., Adult attachment and sexual behavior, „Personal Relationships" 2002, 9, s. 191-204.

Bowlby J., Przywiazanie, Wyd. Naukowe PWN, Warszawa 2016.

Burkett J.P., Young L.J., The behavioral, anatomical and pharmacological parallels between social attachment, love and addiction, „Psychopharmacology” 2012, 224(1), s. 1-26.

84 D. Barrett, Supernormal stimuli-How primal urges overran their evolutionary purpose, W. W. Norton, New York 2010. 
Caldwell C., Addiction as somatic dissociation, w: Flesh of the soul: The body we work with, red. M. Heller \& P. Lang, Berne, Switzerland 2001.

Carnes P., Contrary to love: Helping the sexual addict, CompCare, Minneapolis 1989.

Carnes P., Od nałogu do miłości, Media Rodzina, Poznań 2001.

Cassidy J., Shaver P.R., Handbook of attachment. Theory, research and clinical applications. The Guilford Press, New York, London 2008.

Coleman E., Is your patient suffering from compulsive sexual behaviour? „Psychiatric Annals” 1992, 22, s. 320-325.

Cooper M.L., Shaver P.R., Collins N.L., Attachment styles, emotion regulation, and adjustment in adolescence, ,Journal of Personality and Social Psychology” 1998, nr 74(5), s. 1380-1397.

Cozolino L. The neuroscience of human relationships: Attachment and the developing social brain, Norton, New York 2006.

Cramer B., Strern D.N. Ocena zmian w krótkoterminowej terapii diady matkadziecko, „Nowiny Psychologiczne” 1990, nr 5-6, s. 92 -121.

Creeden K., The Neurodevelopmental Impact of Early Trauma and Insecure Attachment: Re-Thinking Our Understanding and Treatment of Sexual Behavior Problems, ,Sexual Addiction \& Compulsivity” 2004, nr 11(4), s. 223-247.

Erikson E. H., The life cycle completed, W.W. Norton, New York 1982.

Fairbairn C.A., Briley D., Kang D., Fraley C., Hankin B., Ariss T., A Meta-Analysis of Longitudinal Associations Between Substance Use and Interpersonal Attachment Security, „Psychological Bulletin” 2018, nr 144 (5), s. 532-555.

Fairbairn C.E., Cranford J.A., A multimethod examination of negative behaviors during couples interactions and problem drinking trajectories, ,Journal of Abnormal Psychology" 2016, nr 125(6), s. 805-810.

Faisandier K., Taylor J., Salisbury R., What does attachment have to do with out-of-control sexual behaviour? „New Zealand Journal of Psychology” 2011, nr 40(3), s. 19-29.

Ferree M.C., No Stones: Women Redeemed from Sexual Addiction, InterVarsity Press 2010.

Flores P.J., Addiction as an attachment disorder, Jason Aronson, New York 2004.

Flores P.J., Conflict and repair in addiction treatment: An attachment disorder perspective, "Journal of Groups in Addiction \& Recovery" 2006, 1, s. 5-26.

Gentzler A.L., Kerns K.A., Associations between insecure attachment and sexual experiences, "Personal Relationships" 2004, nr 11, s. 249-265.

Gilliland R., South M., Carpenter B., Hardy S., The Roles of Shame and Guilt in Hypersexual Behavior, „Sexual Addiction \& Compulsivity” 2011, nr 18(1), s. 12-29. 
Ginot E., Self narrative and dysregulated affective states: The neuropsychological links between self-narratives, attachment, affect, and cognition, „Psychoanalytic Psychology" 2011, nr 29, s. 59-80.

Goodman A., Addiction: definition and implications, „British Journal of Addiction” 1990, nr 85(11), s. 1403-1408.

Hall P., A New Classification Model for Sex Addiction, „Sexual Addiction \& Compulsivity" 2013, nr 20, s. 279-291.

Höfler D.Z., Kooyman M., Attachment transition, addiction and therapeutic bonding-An integrative approach, ,Journal of Substance Abuse Treatment” 1996, nr 13(6), s. 511-519.

Hudson-Allez G., Infant losses; Adult searches: A neural and developmental perspective on psychopathology and sexual offending, UK: Karnac Books, London 2009.

Insel T.R., Is social attachment an addictive disorder?, „Physiology \& Behavior” 2003, nr 79(3), s. 351-357.

Katehakis A., Sex addiction as affect dysregulation, Sex addiction as affect dysregulation. (s. 119-124). New York: W. W. Norton \& Company, Inc.

Kearns-Bodkin J.N., Leonard K.E., Alcohol involvement and marital quality in the early years of marriage: A longitudinal growth curve analysis, „Alcoholism: Clinical and Experimental Research" 2005, nr 29(12), s. 2123-2134.

Khantzian E.J., Reflections on Treating Addictive Disorders: A Psychodynamic Perspective, „The American Journal on Addictions” 2012, 21, s. 274-279.

Khantzian E.J., The Self-Medication Hypothesis of Substance Use Disorders: A Reconsideration and Recent Applications, „Harvard Review of Psychiatry” 1997, nr 4(5), s. 231-244.

Klein S., Addiction and Attachment: A Complex Relationship. Semantic Scholar, Manuscript from Naropa University's Graduate School of Psychology, published online in 2014. Retrieved from: https://www.semanticscholar.org/ paper/Running-head-\%3A-ADDICITON-AND-ATTACHMENT-1-AddictionKlein/e81d968c6c6cf6cd6a0d4c023a19d73659f59e98\#related-papers [odczyt: 01.09.2018].

Koob G.F., Le Moal M., Drug abuse: Hedonic homeostatic dysregulation, „Science” 1997, nr 278(5335), s. 52-58.

LaFond Padykula N., Conklin P., The self regulation model of trauma and addiction, „Clinical Social Work Journal” 2010, nr 38, s. 351-360.

Leedes R. Theory and praxis: A heuristic for describing, evaluating, and intervening on sexual desire disorders when sexual expression interferes with humanistic expression. „Journal of Sexual Addiction \& Compulsivity” 1999, nr 6, s. 289-310. 
Liebowitz M., The chemistry of love, Liitle, Brown, \&Co, Boston 1983.

Lipton B., Fosha D. Attachment as a transformative process in AEDP: Operationalizing the intersection of attachment theory and affective neuroscience, ,Journal of Psychotherapy Integration” 2011, nr 21, s. 253-279.

Lyons-Ruth K., Jacobvitz D. Attachment disorganization: Unresolved loss, relational violence and lapses in behavioral and attentional strategies, w: Handbook of attachment, red. J. Cassidy, P.R. Shaver, Guilford Press, New York, London 1999.

Madigan S., Brumariu L.E., Villani V., Atkinson L., Lyons-Ruth K. (Representational and questionnaire measures of attachment: A meta-analysis of relations to child internalizing and externalizing problems, „Psychological Bulletin” 2016, nr 142(4), s. 367-399.

Magai C., Affect, imagery and attachment. Working models of interpersonal affect and the socialization of emotion, w: red. Cassidy J., Shaver P.R., Handbook of attachment, Giulford Press, New York, London 1999.

Mate G., In the realm of the hungry ghosts: Close encounters with addiction, North Atlantic Books, Berkley 2010.

Morgan O. Thoughts on the interaction of trauma, addiction, and spirituality. „Journal of Addictions and Offender Counseling” 2009, 30, s. 5-15.

Morgenstern J., Naqvi N., Breiter H., Debellis R., The contributions of cognitive neuroscience and neuroimaging to understanding mechanisms of behavior change in addiction, "Psychology of Addictive Behaviors" 2013, 27, 336-350.

Newcomb M.D., Drug use and intimate relationships among women and men: Separating specific from general effects in prospective data using structural equation models, „Journal of Consulting and Clinical Psychology” 1994, 62(3), s. $463-476$.

Norton \& Company, Inc., New York 2017.

O'Donohue G.B. Out of control sexual behavior: An analysis of various authors' attempts to operationalize a construct. Nieopublikowany manuskrypt, Harvard University, Cambridge 2001, MA.

Obegi J.H., Berant E., Attachment theory and research in clinical work with adults, The Guilford Press, New York 2009:

Reid R., Carpenter B., Spackman M., Willes D., Alexithymia, Emotional Instability, and Vulnerability to Stress Proneness in Patients Seeking Help for Hypersexual Behavior, „Journal of sex \& marital therapy” 2008, nr 34, s. 133-49.

Reid R., Carpenter B.N, Lloyd T.Q., Assessing psychological symptom patterns of patients seeking help for hypersexual behavior, „Journal of Sexual \& Relationship Therapy" 2009, nr 24(1), s. 47-63. 
Reid R.C., Harper J.M., Anderson J.H., Coping strategies used by hypersexual patients to defend against the painful effects of shame, „Clinical Psychology \& Psychotherapy" 2009, nr 16(2), s. 125-138.

Schindler A., Thomasius R., Sack P., Gemeinhardt B., KÜStner U., Eckert J., Attachment and substance use disorders: A review of the literature and a study in drug dependent adolescents, „Attachment \& Human Development” 2005, nr 7(3), s. 207-228.

Schneider J. P., Schneider B. H., Sex, lies, and forgiveness: Couples speaking out on healing from sex addiction, Recovery Resources Press, Tucson 2004.

Schore A. N., Affect dysregulation and disorders of the self. W. W. Norton \& Company, New York 2003.

Schore A.N., Effects of a secure attachment on right brain development, affect regulation, and infant mental health, „Infant Mental Health Journal” 2001, nr 22, s. 27-35.

Senator D., Więź w triadzie matka-ojciec-dziecko jako matryca rozwoju psychicznego dziecka, „Psychologia Rozwojowa - Rodzina jako środowisko rozwoju dzieci i rodziców" 2004, nr 9(2), s. 11-16.

Siegel D. J., Pocket guide to interpersonal neurobiology: An integrative handbook of the mind. W.W. Norton \& Company, New York 2012.

Simpson J.A., Collins W.A., Tran S., Haydon K.C., Attachment and the experience and expression of emotions in romantic relationships: A developmental perspective, "Journal of Personality and Social Psychology" 2007, nr 92(2), s. 355-367.

Sroufe A., Attachment and development: A prospective, longitudinal study from birth to adulthood, „Journal of Attachment and Human Development” 2005, nr 7, s. 349-367.

Van Ijzendoorn M.H., Schuenge C., Bakermans-Kranenburg M.C., Disorganized attachment in early childhood: meta-analysis of precursors, concomitants, and sequelae, „Developmental Psychopathology” 1999, nr 11(2), s. 225-49.

Vungkhanching M., Sher K.J., Jackson K.M., Parra G.R., Relation of attachment style to family history of alcoholism and alcohol use disorders in early adulthood, „Drug and Alcohol Dependence” 2004, nr 75(1), s. 47-53.

Wilkinson M., Undoing trauma: contemporary neuroscience: A Jungian clinical perspective, „Journal of Analytical Psychology” 2003, nr 48, s. 235-253.

Young K. S., Internet sex addiction: Risk factors, stages of development, and treatment, „American Behavioral Scientist” 2008, nr 52, s. 21-37.

Zapf J.L., Greiner J., Carroll J., Attachment styles and male sex addiction. „Journal of Sexual Addiction \& Compulsivity" 2008, nr 15, s. 158-175. 


\section{Źródla internetowe}

Klasyfikacja ICD-11: https://icd.who.int/browse11/1-m/en\#/http://id.who.int/icd/ entity/1602669465

https://pdfs.semanticscholar.org/e81d/968c6c6cf6cd6a0d4c023a19d73659f59e98. pdf?_ga $=2.263075276 .1318850387 .1573814531-792023037.1573814531$ [odczyt: 10.09.2018].

\section{Anna Czyżkowska: Sexual addiction from the attachment theory perspective}

\section{Summary}

Attachment theory is one of the psychological concepts explaining the relationship between early childhood experiences (in relation to caregivers) and many problems in later life (emotional disorders, personality disorders, relationship disorders). Researchers are also trying to use it to explain addiction, especially sex addiction. The path from attachment style in childhood to addiction can lead through a mechanism of disturbed affect regulation, a neurological and cognitive mechanism. The literature also describes the specificity of the family of origin (parenting style, emotional climate) of people addicted to sex. In addition, the socio-cultural etiology of sexual behavior with traits of an addictive personality comes to the fore, apart from early childhood experiences. Researchers postulate to look at sexual behavior in terms of hypersexuality, OCSB (out-of-control sexual behavior) or sex addiction from a new perspective. In the past the people at gmost at risk for addiction (including sexual addiction) were the ones with a tough childhood. However, recent changes in society, culture and technology meant that everyone is equally endangered as our entire environment has become a part of an addiction culture.

Key words: attachment, sex addiction, affect regulation, family psychology, shame theory, addiction cycle, OAT model 